\title{
Developing Language Learning Through English Cartoons and Technological Applications Among Elementary Students - A Study
}

\author{
Waheed Shafiah ${ }^{1}$ and Afsha Jamal ${ }^{2}$ \\ ${ }^{1}$ English Department, St. Ann's College of Engineering \& Technology, Chirala, India \\ ${ }^{2}$ English Department, College of Arts \& Sciences for Girls, PSAU, Wadi Addawasir, KSA
}

\section{ABSTRACT}

Huge developments in Information Technology Sector stress on Spoken Skills in English compelling each child has to learn these skills effectively and perfectly. English as Second / Foreign Language Learning (ESL/EFL) is an unceasing, vibrant, and a long term process compared to any other skills. Plenty of opportunities are opened for the best English language speakers in all the sectors. Hence, the serious introduction of Practical English Sessions in elementary schooling is needed immediately and which resolves all the issues relating ESL/EFL learning globally. Speaking, a productive language skill is in great demand and its implementation at elementary level is highly appreciated. Otherwise it becomes a major drawback when the child goes for further studies or for jobs in his/her future. This article focuses on perceptions of language teachers and parents on improving speaking skills among the language learners since childhood using cartoons that attract children tremendously. As the responsibility is shouldered on parents as well as on English teachers, they have to take utmost care at the childhood stage. Today, though every mother is educated, is not able to spend time with their children to develop their English speaking skills. So, at this juncture, most of the children are neglected and prone to use mobiles with useless games. If children are guided properly with the select English cartoons, then they can develop their English spoken language effortlessly, because children are the real imitators. Several researches also prove that children are quick learners than adults. They grasp everything around them quickly and effortlessly, especially language. The present article adopts a quantitative research methodology and intends to collect data regarding the perceptions of Language teachers and parents on improving speaking skills via cartoons among the children at elementary level of schooling. The findings reveal the significance of cartoons in developing speaking skills among the language learners. It concludes with a few technology-based approaches towards ESL/EFL learning.

\section{KEY WORDS: ESL/EFL LEARNING PRACTICAL SESSIONS, CARTOONS, TECHNOLOGY-BASED RESOURCES.}

\section{INTRODUCTION}

Essential speaking skills in English play a crucial role in everyday situations and career opportunities. English has been considered as one of the important languages in India or in Abroad. Huge developments in Information Technology Sector stress on spoken skills in English and compels that each child has to learn these skills effectively and perfectly. English as Second / Foreign Language

Biosc Biotech Res Comm P-ISSN: 0974-6455 E-ISSN: 2321-4007
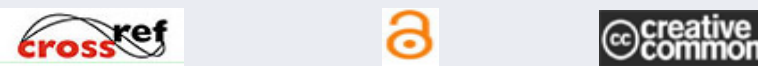

Identifiers and Pagination

Article Information

Year: 2021 Vol: 14 No (8) Special Issue

Pages: 242-245

Received: $10^{\text {th }}$ June 2021

This is an open access article under Creative

Commons License Attribn 4.0 Intl (CC-BY).

DOI: $h t t p: / / d x . d o i . o r g / 10.21786 / b b r c / 14.8 .56$
Learning (ESL/EFL) is an unceasing, vibrant and a long term process compared to any other skills. Hence, plethora of job opportunities unlocks to the best English speakers in every sector and also boosts one's self-confidence.

However, most of the South Indian Rural background students experience different levels of speaking anxiety and inhibitions when they speak English as a second language. Their proficiency level is low when they use English language. They have the fear of an insult, humiliation, hesitation, nervousness and criticism. The inability to speak in English confidently is not only faced by secondary school students but also at undergraduate level. So to reduce such problems, some of the measures have to be taken at the initial level of child's Education i.e., the introduction of Practical English Sessions in elementary school can resolve most of the issues relating to ESL/EFL learning globally. Speaking, a productive

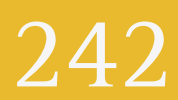


language skill is in great demand and its implementation at elementary level is highly appreciated. Otherwise it becomes a major drawback when the child goes for further studies or for jobs in India or in abroad. This is one of the unavoidable factors to be focused on for better employment of the South Indian students.

This research article focuses on improving speaking skills among the second language learners since childhood. The responsibility is shouldered on parents as well as on English teachers. Today, though every mother is educated, is not able to spend time with their children to develop their English speaking skills. So, at this juncture, most of the children are neglected and prone to use mobiles with useless games. If children are guided properly with the select English cartoons or spoken technological applications, then they can develop their English spoken language effortlessly, as children are the real imitators. Technological applications like Siri in IPhone, Google talk in all smart phones, Alexa gadget and the select English cartoons can help children to build their confidence since the primary level. The fact is that Cartoons and mobile applications attract children tremendously.

Video and Audio-based applications are designed to get a desired expectation of being confidence while speaking English language. These applications are not new to us. It allows the children to speak without monitoring or help. Several researches also have focused that children are quick learners than adults. They grasp everything around them quickly and effortlessly, especially they imitate cartoon characters language. The present article adopts a quantitative research methodology and intends to collect data regarding the perceptions of Language teachers and parents on improving speaking skills via Siri in IPhone, Google talk, Alexa gadget, and the select English cartoons among the children at elementary level of schooling. The findings reveal the experiences of parents on certain parameters on developing English Language besides the significance of all technological applications develop speaking skills among the language learners. It concludes with a few technology-based approaches towards ESL/EFL learning.

Literature Review: Coming to the literature survey, many researchers have focused on technology based approaches but with different applications. In the article, Developing Speaking Skills Using Virtual Speaking Buddy by Radzuwan AB Rashid University Sultan Zainal Abidin, Malaysia has mentioned about "V-Buddy, which is an audio-based application designed to propose a possible solution to overcome students' lack of confidence to speak in English. As argued by recorded audio is 'a rich, flexible and engaging learning space' for the students in Malasia."

Another research article entitled The Use of Cartoons for Developing the Skills of Understanding and Analyzing of Children in Preschool Period by Rezan Karakas mentioned that Cartoons are a kind of art that reveal all incidents associated to social dealings with a humorous style of thinking. "In preschool period, cartoons are used as a tool for development of the children's mother tongue. Child's physical and mental development occurs by providing cartoons at home, nursery or kindergarten. So that, the first steps have been taken for the road going from the cartoons of which main material is line to the literature of which main material is language. Cartoons that can be combined with a sense of wonder during preschool period will play an important role in the development of the child's visual reading skills and speaking skills".

In another Journal Proceedings of the International Conference of Early Childhood Education (ICECE 2019) article entitled An Analysis of the Impact of the Use of Gadget on Children's Language and Social Development by Dewi Nilam Sari \& Dewi Nilam Sari has mentioned that "many of the impacts and benefits of the gadgets among others, to facilitate a child in a child's creativity and intelligence. As the application of coloring, learning to read and write letters certainly a positive impact on brain development of children. Children do not entail much time and exertion to learn to read and write in a book or paper. Children are ever excited to acquire because such applications are usually complemented by interesting pictures and writing letters is certainly a positive impact on brain development of children".

\section{METHODOLOGY}

The present study administers questionnaire to collect information regarding the role of cartoons in language learning process. The participants are parents and teachers who play a great role in shaping the future of their children and students respectively.

\begin{tabular}{|c|c|c|}
\hline \multicolumn{2}{|l|}{ Male } & Female \\
\hline \multicolumn{2}{|l|}{$15.6 \%$} & $84.4 \%$ \\
\hline \multicolumn{3}{|l|}{ Table 2} \\
\hline Doctorate & Masters & Bachelor \\
\hline $31.25 \%$ & $45.3 \%$ & $23.4 \%$ \\
\hline
\end{tabular}

Data Analysis: This study presents descriptive-analysis based on primary as well as secondary data. The first query is to find out the gender of the respondents. Out of 64 respondents 10 are male while remaining 54 are female. The qualification of the respondents is probed and the replies vary largely. Out of 64 participants 20 completed the Doctorate degree, while 29 did Masters and remaining 15 hold Bachelor's degree. The study has administered the questionnaire purposefully among teachers and parents who occupy various positions in their respective places while a few are unemployed. Out of 64 respondents 10 are engineers, while 14 private employees, 11 university professors, 18 school teachers, 
2 bank employees and remaining 8 are housewives. The responses for the query whether children learn English language better under guidance 58 participants agreed while only 6 denied.

\begin{tabular}{|l|c|l|c|c|l|}
\hline Table 3 & Engineers & $\begin{array}{c}\text { Private } \\
\text { Employees }\end{array}$ & $\begin{array}{c}\text { Bank } \\
\text { Employees }\end{array}$ & Housewives \\
\hline Professors & Teachers & Emplo & $14 \%$ \\
\hline $17.1 \%$ & $28.1 \%$ & $15.6 \%$ & $21.8 \%$ & $3.1 \%$ & $1 \%$ \\
\hline
\end{tabular}

\section{Figure 1}

\section{Children learn English better under guidance}

6.4 responses

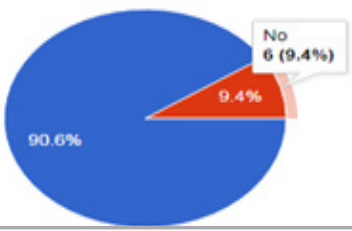

The researchers felt the need to find out if the teachers and parents allot their time to improve their oral skills in English. The replies indicate 51 of them follow while a few 13 of them don't. The present study reveals that only 61 replied to the query how long their children practice English language at home. 47 replied that their children practice English language about 30 minutes a day while 14 of them confess about 60 minutes at home and the remaining 3 have skipped replying indicating their children never practice at home. The researchers elicit information regarding the participants' views on the sources that motivate children in learning English. Out of 64, majority of them 39 feel they are motivated a lot by cartoons, while 16 reading stories, only 3 classwork and the remaining 6 others.

\section{Figure 3}

How much time do children practice English Language at home?

61 responses

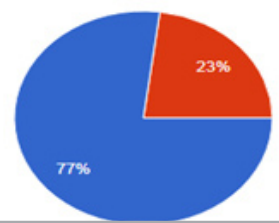

Figure 4

Children are motivated a lot in learning English through..

64 responses

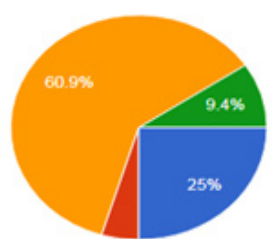

- Reading stories - Classwork Cartoons - Others
Figure 2

po you spend your time to develop your child's spoken skills in English? 4 responses

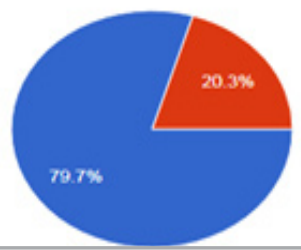

- yes

Figure 5

I think cartoon dialogues are easy for kids

63 responses

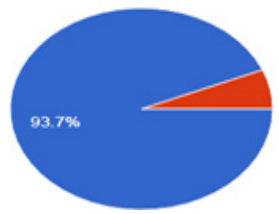

Figure 6

How do children spend thier free time

st responses

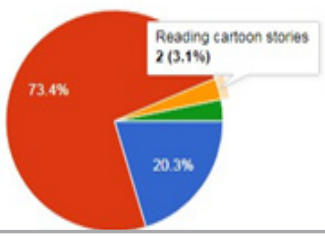

Plaving

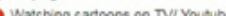
Reading cantoon stonies

other

Figure 7

Have you observed that children normally imitate characters language from the cartoons 64 responses

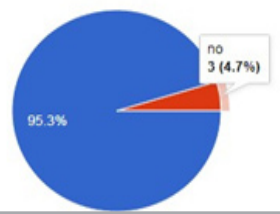

yos

The study focuses on the usage of cartoon dialogues by kids. Accordingly, out of 64 participants, only 59 accepted that cartoon dialogues are easily acquired by children; only 4 of them disagreed while 1 left it unanswered. The study concentrates further on the free 
time spent by the children and it is revealed that 47 of the respondents replied that they spend on watching cartoons on T.V and you tube channels, while 2 expressed they read cartoon stories, 13 mentioned that kids play and 2 opined other sources. The next query is their agreement on the impact of cartoon dialogues on the children profusely. 61 participants agree that children imitate their favourite characters from the cartoon network series and the remaining 3 of them disagreed. Out of 64 respondents, 34 expressed that they children learn around 10 words per day while watching cartoons, while 24 replied more than 10 words, 5 responded not a single word while 1 remained neutral by not responding to the query.

\section{Figure 8}

How many English words do children use from cartoons in a day?

33 responses

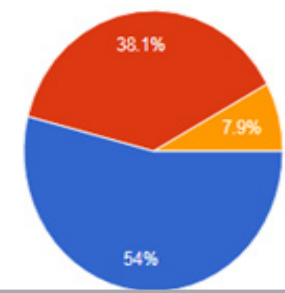

Figure 9

Do you strongly believe that a child can learn English language from cartoons with less effort ?

63 responses

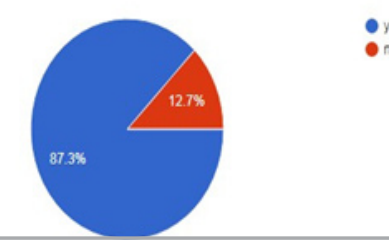

Figure 10

Do children speak English at home?

53 responses

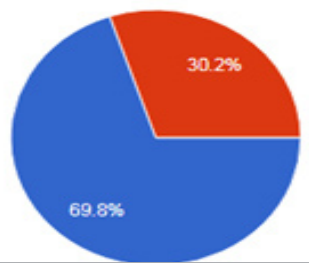

55 participants accepted that a child learns English language with less effort, while 8 disagreed and 1 remained neutral. Out of 64 respondents 44 agreed that children speak English at home, while 19 responded that they never and 1 remained neutral. The final query is based on the query that exposes the rate of learning English from cartoon dialogues by the children. 44 rated above 5 points and 20 below 5 points. The above data shows parents opinion very clearly on certain parameters
Figure 11

How much rating do you give on a scale of 1 to 10 points that children learn from English Cartoons

54 responses

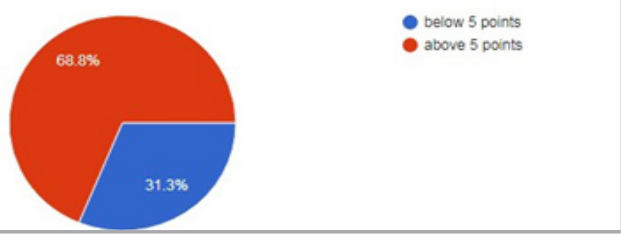

in developing English Language. At the same time, some more real examples are added in this article. Many small children below five years old uses cartoon language in their daily life. Many children from our families, friends and relatives are observed carefully, and the study reveals that children imitate cartoon characters language definitely which may be Hindi, Telugu or English. So it is our responsibility to guide them properly in cartoons or other application.

\section{CONCLUSION}

Based on global demands, we have to adopt learning from the new world of digital-education. In addition to this, Children can get needed daily inputs. It may turn into a more meaningful activity. This method has proven successful in many different places with different children. Technology is the most effective tool for child's growth. Hence, it is especially important for the teacher as well as parents to be made clear of their responsibilities when engaging the students English Cartoons and other applications like Siri in IPhone, Google talk in all smart phones and Alexa gadget.

\section{REFERENCES}

Available at https://www.researchgate.net/ publication/343178201_An_Analysis_of_the_Impact_ of_the_Use_of_Gadget_on_Children's_Language_and_ Social_Development

Dewi Nilam Sari (2020). An Analysis of the Impact of the Use of Gadget on Children's Language and Social Development, Proceedings of the International Conference of Early Childhood Education (ICECE 2019). Advances in Social Science, Education and Humanities Research. ISSN 2352-5398. Vol 449, 201-204 pp.

Radzuwan Ab Rashid(2017). Developing Speaking Skills Using Virtual Speaking Buddy.

International Journal of Emerging Technologies in Learning (iJET) 12(05):195-201. Available at https://www.researchgate.net/publication/317266197_ Developing_Speaking_Skills_Using_Virtual_S peaking_ Buddy

https://www.sciencedirect.com/science/article/pii/ S1877042812017399

Rezan Karakas (2012) The Use of Cartoons for Developing the Skills of Understanding and Analyzing of Children in Preschool Period. Procedia - Social and Behavioral Sciences 463026 - 3030. 